\section{High technology protectionism}

Colin Norman reports from Washington on US efforts to control the export trade in strategic technology being stimulated by the era of "détente"

A REPORT which has so far received scant public attention, but which is now being closely studied in the Pentagon, contains a number of startling and disturbing recommendations for controlling trade in high technology goods between western nations and the Soviet Union. Prominent among them is the suggestion that the United States should apply tough sanctions against any countryincluding America's European allieswhich passes potentially strategic technology to a communist country. It also recommends that the Department of Defense should keep a close watch on government-to-government scientific exchange agreements and that it should keep its eye on the training of people from communist countries at major institutes and universities in the United States.

The report, published by the Defense Science Board (DSB), a top-level Pentagon advisory group, is the latest in a series of outpourings of concern that the United States' lead over the Soviet Union in strategic areas of technology is gradually being whittled away by commercial sales of computers, electronic goods and similar items. Such trading has mushroomed in the past few years through the establishment of the Nixon-Kissinger policy of detente with the Soviet Union.

The DSB report, prepared at the request of senior Pentagon officials and written by a task force headed by J. Fred Bucy, vice-president of Texas Instruments, argues that national and international arrangements for controlling east-west trade have not been effective in preventing strategic technologies from leaking eastwards through commercial channels. It therefore argues for a new approach, including some harsh sanctions to prevent such transactions.

Trade between the United States and communist countries has been controlled since the beginning of the cold war by a mechanism operated by an office in the Department of Commerce called the Office of Export Administration (OEA). A company wishing to export a strategically sensitive product or technology, as defined in a docu. ment known as the Commodity Control List, must apply to OEA for a licence.
The application is reviewed by an interagency committee composed of representatives from the Departments of State, Defense, Commerce, the Energy Research and Development Administration, and the CIA. Approval is given only to those transactions deemed unlikely to improve the Soviet Union's military capabilities.

A measure of western conformity in such matters is provided by an arrangement known as the Consultative Group Coordinating Committee (CoCom), consisting of representatives from NATO member countries, excluding Iceland but with the addition of Japan. CoCom maintains a list of restricted products similar to the US Control List, and its members have informally agreed to follow similar procedures in licensing exports to communist countries.

Although both the US Commodity Control List and the CoCom list have recently been brought up to dateduring the height of the cold war they were said to contain such strategic items as brassieres and wigs--the DSB task force suggests that they still contain many products of little military value. Instead of wasting time on such items, the task force suggests that the list should be drastically shortened and more effort should be put into curtailing the transfer of vital design and manufacturing knowledge. Particularly close attention, it indicates, should be paid to deals involving the transfer of turnkey factories, products requiring sophisticated maintenance and operating information, and items resulting from a revolutionary technological advance.

The report argues that controls have broken down in recent years because "CoCom members have perceived less of a need to maintain strict controls while the opportunity for individual gain through the sale of technology to communist countries has increased. As a result, strategic technology has been transferred to communist nations through CoCom-sanctioned exceptions, ambiguous interpretations of lists, and, perhaps, conscious violation of CoCom agreements". The task force therefore suggests that the United States should try to bully CoCom countries into adhering to export control agreements by imposing "a sanction on any CoCom country that fails to control a specific technology, by restricting the flow of know-how in that technology to the offending country".

Another reason why controls have broken down, the task force argues, is that firms in some countries which import US technology promptly reexport it to the Soviet Union, in violation of international agreements. Though the United States already attempts to stop such transactions by blacklisting firms thought to be engaging in such practices, the task force argues that some strong-arm tactics are in order here, too. "A nation that allows strategic technology to be passed on to a communist country should be restricted from receiving further technology of US origin", it states.

Moreover, the task force suggests that the United States "should release to non-allied, non-communist countries only the technology we would be willing to transfer to communist countries directly". In that regard, the task force states that "of particular concern is the acquisition of high technology know-how by nations of the middle east, and the assimilation of know-how by nations of Western Europe that are not members of CoCom-principally Switzerland, Sweden and Austria".

Though the bulk of the report deals with transfer of strategic technology through commercial channels, it also notes that recent scientific exchange agreements between the United States and the Soviet Union have greatly increased the movement back and forth of scientists between those two countries. Such agreements, Bucy notes in a covering letter to the report, are potentially "an area of concern".

The task force, finally, comes up with a recommendation that the Department of Defence should conduct a "comprehensive study of active mechanisms for transferring technology that are beyond the normal scrutiny of export control administration", and that it should develop recommendations for "monitoring and controlling them". Among such mechanisms, the task force lists "the use of US citizens as consultants for key technologies by communist countries", "the participation of US citizens as principals in firms established outside the US and engaged in transferring embargoed technology and products to communist nations", and "the training of citizens from communist countries at the more significant laboratories of US technical institutes and universities".

The task force report was approved for publication by Malcolm Currie, Director of Defense Research and Engineering. which suggests that it at least has his general approval. An internal task force has now been established in the Pentagon to evaluate the report and to recommend if, and how, its recommendations should be implemented. 